\title{
Analysing the Outcomes of the Forestry Sector on the Sustainable Development Goals for Rural Communities: A Case Study of Cabrero, Chile
}

\author{
Veronica Gonzalez-Navarro ${ }^{1,3}$, Julia Tomei ${ }^{1,2}$ \& Gabriela Flores-Oyarzo ${ }^{3}$ \\ ${ }^{1}$ UCL Institute for Sustainable Resources, University College London, London, United Kingdom \\ ${ }^{2}$ UCL Energy Institute, University College London, London, United Kingdom \\ ${ }^{3}$ Programme for Social Responsibility Studies (PERS), University of Concepcion, Concepcion, Chile \\ Correspondence: Veronica Gonzalez-Navarro, Programme for Social Responsibility Studies (PERS), University \\ of Concepcion. Victor Lamas 1290, Concepcion, Chile. Tel: 56-4-1220-3037. E-mail: mariavgonzalez@udec.cl
}

Received: July 17, 2018 Accepted: August 21, $2018 \quad$ Online Published: September 28, 2018

doi:10.5539/jsd.v11n5p194

URL: https://doi.org/10.5539/jsd.v11n5p194

This research was supported by the Comisión Nacional de Investigación Cientifica y Tecnológica (Chilean National Commission for Scientific and Technological Research) 'Becas Chile' Master Fellowship Programme; Grant No.73170195. Special thanks to the Programme for Social Responsibility Studies (PERS) of the Universidad de Concepcion, Chile; this study was possible thanks to its academics, professionals and students.

\begin{abstract}
The forestry sector will play a key role in the achievement of the 2030 Agenda for Sustainable Development. The forestry sector is a pillar of many countries' economies, including Chile. Despite the many economic benefits of the sector for the country, its contribution to the achievement of the Sustainable Development Goals (SDGs) is not clear, especially for rural communities that co-exist with the sector. This study therefore aimed to identify the impacts of the sector on the sustainable development of rural communities in a Chilean commune, Cabrero, and link these impacts to the SDGs. Based on a mixed-method approach that considers key stakeholders perspectives, the paper finds that the forestry sector has multiple and complex impacts on sustainable development, with both positive and negatives outcomes for rural communities, generating synergies and trade-offs with all of the 17 SDGs. It concludes that while companies play a key role in delivering the 2030 Agenda, the achievement of the SDGs will require collaboration amongst people, government and the private sector to understand and support the delivery of a forestry sector that contributes to the sustainable development of communities in Cabrero and, more generally, in Chile.
\end{abstract}

Keywords: forests, the 2030 Agenda, sustainable development, rural development, Chile, community

\section{Introduction}

Forest are essential to the achievement of sustainable development. As described in the 1987 Brundtland Report, forests contribute to sustainable development through multiple channels - by protecting and enhancing ecosystems, creating habitats, contributing to climate systems, and protecting soils and watersheds. In addition, forests are a source of economic and social development through the provision of timber and non-timber forest products (World Commission on Environment and Development, 1987). Given the multi-functionality of forests and their capacity to provide a range of ecosystem services, they are expected to play a crucial role in the achievement of the United Nations' 2030 Agenda for Sustainable Development. The 2030 Agenda is comprised of 17 Sustainable Development Goals (SDGs) and 169 Targets (see e.g. Interagency and Experts Group on Sustainable Development Goals Indicators, 2015). Of the 17 SDGs (Figure 1), two explicitly mention forests SDG6 (Clean Water and Sanitation) and SDG15 (Life on Land) - although many more involve the conservation and sustainable use of forests. Seymour and Busch (2016) explore the many ways in which tropical forests contribute to the 2030 Agenda and describe the ways in which tropical forests, through the delivery of ecosystem services, impact directly on the achievement of not only SDGs 6\&15, but also SDG2 (Zero Hunger), SDG3 (Good Health and Well-being), SDG7 (Affordable and clean energy), SDG11 (Sustainable Cities), and SDG13 
(Climate Action). Furthermore, Milledge (2015), argues that forests have the ability to contribute to all of the SDGs, through the provision of different ecosystem services and the creation of enabling conditions, such as enhanced institutional capacity to manage the multi-functionality of forests.

While forests will contribute to the 2030 Agenda at the global level, they will be equally important at the local, community level (De Jong, Pokorny, Katila, Galloway \& Pacheco, 2018; Milledge, 2015). Rural communities benefit directly from the many ecosystem services provided by forests such as the provision of income and employment, access to energy, water purification, shelter, medicines and regulation services for agriculture (Food and Agriculture Organisation [FAO], 2017). However, not all forests will contribute to the achievement of the SDGs equally. The role of forests for the sustainable development of rural communities is less clear cut when a forest's main purpose is to provide the raw materials for forest-based industries. Understanding how the forestry sector contributes to the sustainable development of rural communities will be important for achievement of the SDGs. According to Lebedys (2004), the forestry sector includes all the economic activities that are dependent on the production of goods and services from forests. This may include forestry and logging, the production of wood fibre for industrial round wood, wood fuel, charcoal, sawn wood, wood-based panels, pulp and paper. The forestry sector is an important pillar of many national and local economies, especially in developing countries, where the impacts of the sector on the sustainable development of rural communities, is likely to be conditioned by a company's economic, social and environmental practices.
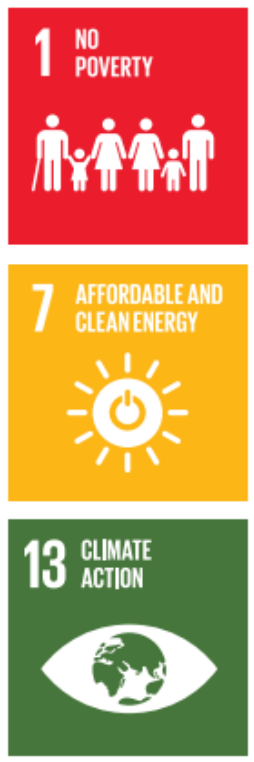
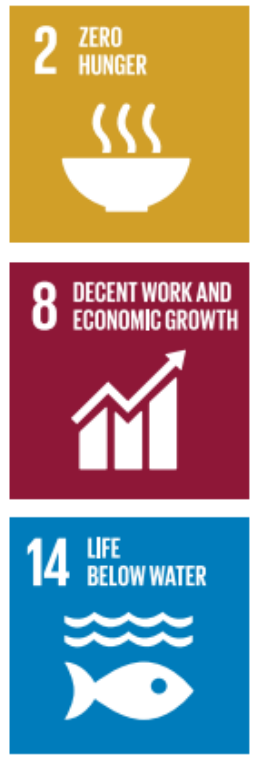
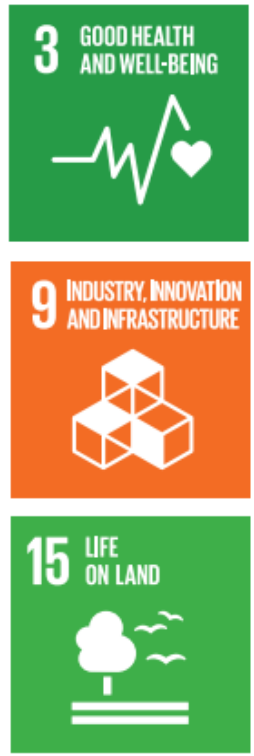
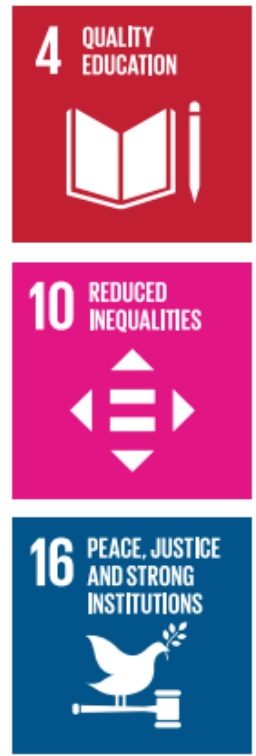
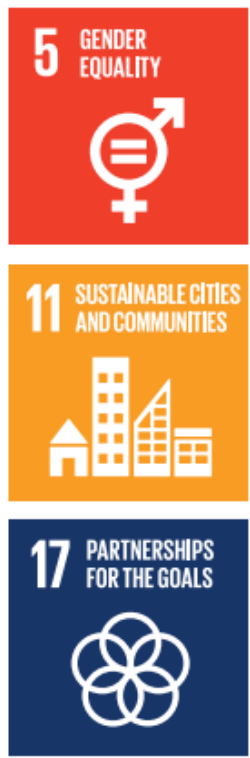
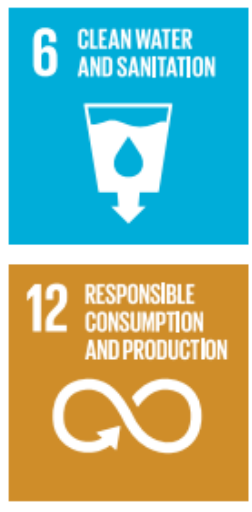

Figure 1. Sustainable Development Goals. Source: United Nations, 2018

Chile is an example of a country where the forestry sector has become a fundamental pillar of its economy. Forestry contributes $2.6 \%$ to GDP, accounts for almost $11 \%$ of the national exports, and directly and indirectly employs around 300,000 people (Chilean Corporation of Timber [CORMA], 2018a). Most of the activity is located in rural areas between Valparaiso and Los Lagos regions and, in particular, the Biobio region. The Biobio region accounts for $40 \%$ of national productive forests and $24 \%$ of forest-based industries, in addition to almost half of the jobs created by the sector (CORMA, 2018a). However, little research has been conducted on the ways in which the forestry sector impacts on the sustainable development of rural communities, and how companies, local government and communities can change their practices to contribute to the 2030 Agenda. Tricallotis and Kanowski (2016), however, provide possible links and questions that might arise when analysing the contribution of sector to SDGs in the Chilean context. Building on this analysis, this paper identifies the impacts of the forestry sector on the sustainable development of rural communities in a commune of the Biobio Region, Cabrero, and link these impacts to the SDGs.

\subsection{The Role of the Private Forestry Sector in Achieving the 2030 Agenda}

The private sector has a key role to play in the achievement of the SDGs. It is fundamental not only due to the impacts their operations could have on society and environment, but also for a company's own business and operations. This may include, for example, new market opportunities, efficiency increases, innovation, and 
reputational risk (Business and Sustainable Development Commission, 2017). The International Organisation for Standardisation (2016) argues that the private sector can contribute to the SDGs through Corporate Social Responsibility (CSR) practices. CSR is defined by the European Commission (2011, p.6) as the 'responsibility of enterprises for their impacts on society'. According to this definition, it is the responsibility of the company not only to adhere to the legislative framework of the country in which it is located, but also to voluntarily engage in the economic, social and environmental conditions of the context in which it operates. This voluntary engagement is especially important for the forestry sector in developing countries where CSR practices may address legislative gaps that regulate the operation of the sector (FAO, 2012; Galloway, Kenges, Louman, Stoian \& Mery, 2006). In this context, a key challenge in the contribution of the sector to the 2030 Agenda relates to the management of forest plantations and forest-based industries.

Plantations or productive planted forests are defined as trees established by planting and/ or seeding of native or exotic species, as result of afforestation or reforestation, that aim to produce wood and non-woods products (FAO, 2010). Plantations are widely used in the forestry sector because they reduce pressure on natural forests while satisfying increasing global demand for forest products (Warman, 2014). Among plantations, intensively managed monocultures are used as a raw material for wood fibre processing industries. Monocultures are productive plantations of one type of species, generally exotic, such as eucalyptus and pine, which through intensive silvicultural practices (Note 2) provide higher average yields of usable wood in short rotation than natural forests or polycultures plantations (O'hehir \& Nambiar, 2010). While monocultures are more efficient in the production of wood fibre, they provide fewer ecosystem services when compared to natural forests or polyculture plantations. Examples of its lower capacity to provide ecosystem services include a reduced capacity to support biodiversity, nutrient cycling and soil formation (Baral, Guariguata \& Keenan, 2016; Brockerhoff, Jactel, Parrotta \& Ferraz, 2012; Felton et al., 2016; Stephens \& Wagner, 2007); water purification, biological control and pest management, adaptation to climate change and the risk of forest fires (Baral et al., 2016; Brockerhoff et al., 2012; Felton et al., 2016; Peña-Fernandez \& Valenzuela-Palma, 2004); the provision of habitat, food and natural medicines (Baral et al., 2016; Brockerhoff et al., 2012); and reduced cultural and recreational services (Felton et al., 2016, Muñoz-Pedreros, 2017). Therefore, the sustainable management of monoculture plantations is a priority for the development and wellbeing of rural communities (Bleyer, Kniivilä, Horne, Sitoe \& Falcão, 2016; D’Amato, Rekola, Wan, Cai \& Toppinen, 2017; Landry \& Chirwa, 2011; Miller \& Buys, 2014).

Sustainable Forest Management (SFM) is understood as the management and use of forest resources at a rate that allows the forests to maintain their ecological, economic and social functions for present and future generations (Ministerial Conference on the Protection of Forests in Europe, 1993). According to Kelty (2006), sustainably managed plantations are recognised for their ability to sequester carbon and restore degraded lands. In addition, plantations could contribute to the mitigation and adaptation of climate change and the impacts on food production by stabilising soils, climate and water flows and enabling pollination (FAO, 2016). Also, as highlighted by May, England, Raison and Paul (2012), forest products from plantations have low embodied energy and, when used as a source of bioenergy have a strong potential for greenhouse gas (GHG) reduction. Regarding the specific contribution of monoculture plantations to the 2030 Agenda, the literature is scarce; however, a report by the Forestry Stewardship Council (FSC), argues that certified forests, including monocultures, have a positive role to play in 11 of the SDGs (FSC, 2016). The FSC promotes best practice in the sector, encouraging companies and forest managers to adopt best practices to prevent deforestation and forest degradation, as well as maintain biodiversity and ecosystem function. The provision of ecosystem services from the sustainable management of certified forests has knock-on impacts on multiple SDGs, specifically: contribution to sustainable food production systems and resilient agricultural practices (SDG2); protection and restoration of water-related ecosystems (SDG6); carbon storage and removal (SDG13); and, promotion of sustainable consumption and production practices (SDG12). In addition, certification by the FSC requires forest owners and managers to develop CSR practices that contribute to community development. This could include: development of health (SDG3) and education (SDG4) facilities; working practices that promote gender equality (SDG5); water quality (SDG6); increased resource efficiency through the wood processing and re-use of waste (SDG12); and the provision of employment, decent work and equal pay (SDG8). Finally, forest governance mechanisms can promote peace, justice and strong institutions (SDG16 - through efforts to promote legal rights to forest exploitation, involve local communities, and mechanisms for conflict resolution), and promote partnerships for sustainable forestry management (SDG17).

The Finish Forest Industries Federation (2017) identified further contributions of the sector through forest-based industries. For example, these sectors could contribute to SDG6 and SDG7 through the efficient use of water and 
energy resources in wood fibre processing plants. In addition, the use of the waste generated in the plants for further productive processes contribute to the industrial symbiosis and, therefore, to SDG9 (industry, innovation and infrastructure). Finally, according to the Federation, the application of a business model based on a circular economy and the commercialisation of products based on a renewable and biodegradable resource, have the potential to contribute to SDG2, SDGs11-15, and SDG17.

Having described how the forestry sector may contribute to the achievement of the 2030 Agenda, the following section turns to the case study country that is the focus of this paper - Chile. In particular, it focuses on the impacts of the sector on rural communities in Cabrero, a commune in the Biobío region (Note 1).

\subsection{The Chilean Forestry Sector and the Impacts on Rural Communities}

According to Payn et al. (2015), Chile is the country with the highest increased rate of planted forest area between 2010 and 2015, reaching 3 million hectares (Mha) of planted forest in 2015. Of these, $98 \%$ correspond to productive plantations which were used as an input to produce industrial round wood (Jürgensen, Kollert \& Lebedys, 2014). Chile is fifth globally in round wood production, and second in South America - preceded only by Brazil (Payn et al., 2015). The sector started to gain dominance in the 1970s following a series of structural economic policies, including the liberalisation of the economy and the declaration of legislative Decree 701 (DL701) (Andersson, Lawrence, Zavaleta \& Guariguata, 2016). DL701 aimed to encourage reforestation of eroded soils or degraded land by providing subsides for companies, which covered up to $75 \%$ of the costs incurred by plantations (Cid, 2015). This led to a rapid expansion of plantations and, eventually, to the development of globally recognised forestry enterprises. Today, the forestry sector is completely privatised and is characterised by the concentration of the activity in three large business conglomerates - CMPC, Arauco and MASISA - which provide global markets with round wood, pulp, chips, sandwood, paper, paperboards, panels and veneers (Tricallotis, 2016). Chilean plantations are mostly monocultures of Pinus radiata, Eucalyptus globulus and Eucalyptus nitents (National Forestry Institute [INFOR], 2017a), which are owned by large conglomerates (63\%) and small and medium forest owners (34\%) (Tricallotis \& Kanowski, 2016).

The forestry sector is located in the central-southern zone of Chile, but most of the activity is concentrated in the Biobío Region, where $70 \%$ of national exports are produced. In this region, there are several communes, or rural territories, surrounded by plantations and forestry industries. The impacts of the value chain of the Chilean forestry sector (Figure 2) on these communities has been studied previously, providing evidence of the multiple impacts on rural communities. For example, the Programme for Management and Environmental Economy (PROGEA, 2014) analysed the multiple economic contributions of the sector to the region in terms of GDP, employment and added value. This report found the sector reduced poverty in rural communities through the generation of alternative sources of income, and stated that the sector could be considered 'a stimulus for the economic dynamism of rural areas' (p.10). Conversely, Benedikter and Siepman (2015) concluded that communities rarely benefit from commercial plantations and remain in poverty and a state of underdevelopment. Andersson et al. (2016) reached similar conclusions and found a positive correlation between land area planted with forestry monocultures and poverty. When analysing the difference in perception between stakeholders in the region, Fawaz (2015) concluded that the macroeconomic benefits of forestry was recognised by all stakeholders, but that at the local level the sector was negatively perceived due to a lack of employment opportunities, loss of land for other economic activities, such as agriculture, and limited interest from companies in engaging in initiatives that contribute to community development. Other studies have highlighted the contribution of plantations to the environment; for example, the National Forestry Corporation describes the Chilean forestry sector as 'one of the best examples of sustainable development in the world' due to the renewable capacity of plantations (CONAF, 2013, p.30). In addition, CORMA (2018b) highlights the contribution of plantations to climate change mitigation, soil recovery and watershed management. PROGEA (2014) discusses the contribution of the sector to renewable energy through the use of its own residues as a source of energy production. By contrast, Cid (2015), Peña-Fernandez and Valenzuela-Palma (2004) and Torres-Salinas et al. (2016) argue that plantations in the Biobío region are often managed under unsustainable silvicultural practices that affect water resources, increase chemical pollution, as well as increase the risk of forest fires and its consequences to communities. In terms of the opportunity costs of land use for plantation forestry, CONAF (2013) argues there is no opportunity cost due the quality of the soils where plantations are located. Other authors, however, find that the replacement of native forest and agricultural lands with monocultures has had negative outcomes for the provision of ecosystem services (Miranda, Altamirano, Cayuela, Lara \& González, 2017; Torres, Azócar, Rojas, Montecinos, \& Paredes, 2015). These authors also find that the change in livelihood strategies generates a climate of injustice and has led to resistance from peasants and indigenous groups, such as the Mapuches. These conflicts have also been exacerbated by the impacts of wood fibre processing industries on 
communities (Cid, 2015).

In recognition of the negative effects of the forestry sector on rural communities and environments, forestry companies in Chile have worked to improve their practices. Many companies have adopted CSR practices and signed up to voluntary certification schemes, such as the FSC and the Chilean system of forest certification (CERTFOR), which has improved the sustainable management of monocultures and governance practices (Tricallotis \& Kanowski, 2016). The adoption of such schemes is vital due to a lack of a national policies to safeguard rural communities against negative environmental and socioeconomic externalities from plantations (Tricallotis \& Kanowski, 2016). Plantation management is regulated by decree DL701 (amended in 1998 by Law 19561 ), which, in addition to encouraging afforestation with plantations and recovery of degraded land, seeks to ensure that plantations are managed sustainably through a forest management plan (CONAF, 2016a). However, such plans rarely incorporate the socioeconomic effects of plantations on local communities, nor do they analyse impacts on ecosystem services (see CONAF, 2018b). The voluntary actions that companies undertake to contribute to the sustainable development of communities is of key importance, especially for those communes which are dominated by the forestry sector, such as Cabrero.

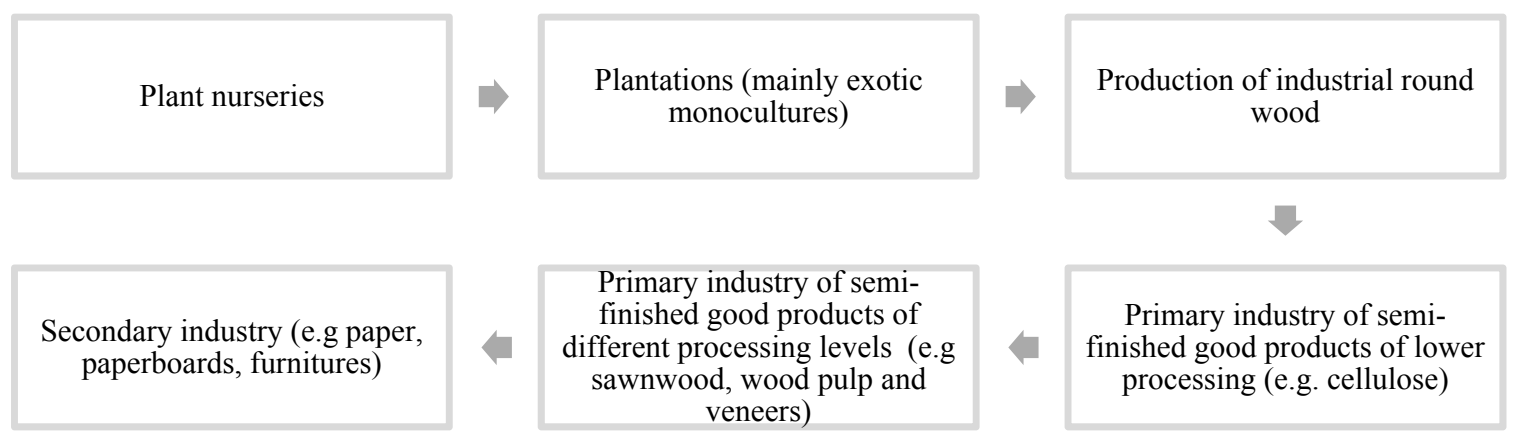

Figure 2. Forestry sector value chain

Source: Departamento de Economía Universidad de Concepción, 2009

\section{Method}

\subsection{Study Area}

Cabrero is a commune located in the Biobío region in Central South Chile (Figure 3). In 2017, the commune had an estimated population of 29,563 inhabitants; of which $29 \%$ lived in rural areas - distributed in 48 rural communities (National Institute of Statistics [INE], 2017a; Municipality of Cabrero, 2013). According to the National Survey of Socio-Economic Characterisation, 31\% of households in Cabrero were in income poverty, which is higher than regional (22\%) and national (14\%) levels (Library of National Congress of Chile [BCN], 2015). In addition to high levels of poverty, there are also significant differences in social progress between urban and rural areas. The greatest differences relate to access to basic human needs such as, drinking water and sanitation, levels of education, and access to information and communication (Programme for Social Responsibility Studies, 2016). 


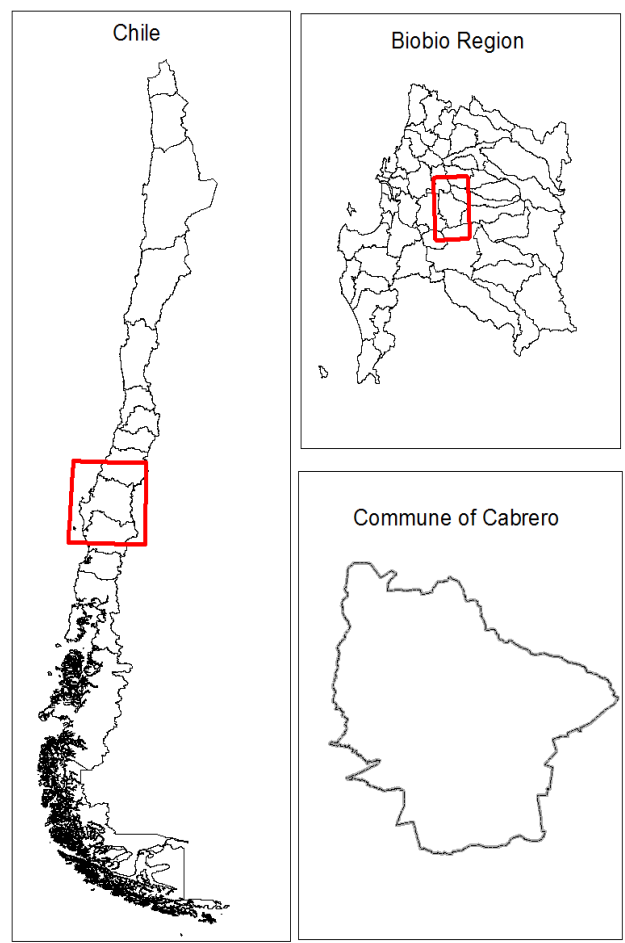

Figure 3. Geographical location of Cabrero

Source: Authors' elaboration based on (INE, 2016, 2017b)

In Cabrero, the main economic activities are the service industry, manufacturing and primary activities, such as agriculture and forestry. Rural economies are dependent on the extraction and management of natural resources, including forestry, organic agriculture, dehydrated products (e.g. mushrooms), beekeeping, vineyards, vegetables, livestock, flower cultivation, and rural tourism (Municipality of Cabrero, 2018). Forestry, however, is the most important sector for the commune in terms of both employment and economic activity, and plays a crucial role in regional exports (Barrera \& Gormaz, 2009; Falabella \& Gatica, 2014; Municipality of Cabrero, 2013). The sector is predominantly located in rural areas (Figure 4), although there are forestry-based industries located in the urban limits of Cabrero city. There are 17 forest-based industries, which cover all aspects of the value chain from nurseries to sawmills, and from chipper to board factories (INFOR, 2017b). There are 233 registered productive forest land, which cover 26673 ha or $42 \%$ of the commune's area (INE, 2007). Around $82 \%$ of this area is planted with forestry monocultures, specifically Pinus radiata and Eucalyptus globulus. As at the national level, the local forestry sector is dominated by the three largest companies in the country. CMPC - through its subsidiary Forestal Mininco - owns plantations and a sawmill. Arauco - through its subsidiary Forestal Celco owns plantations and a plant nursery. MASISA has the largest operations in the commune. The company owns a large sawmill and chipper and also manufacture different types boards, playing a key role not only in the dynamism of the communal economy but also contributing to regional and national exports (Fallabella \& Gatica, 2014). 


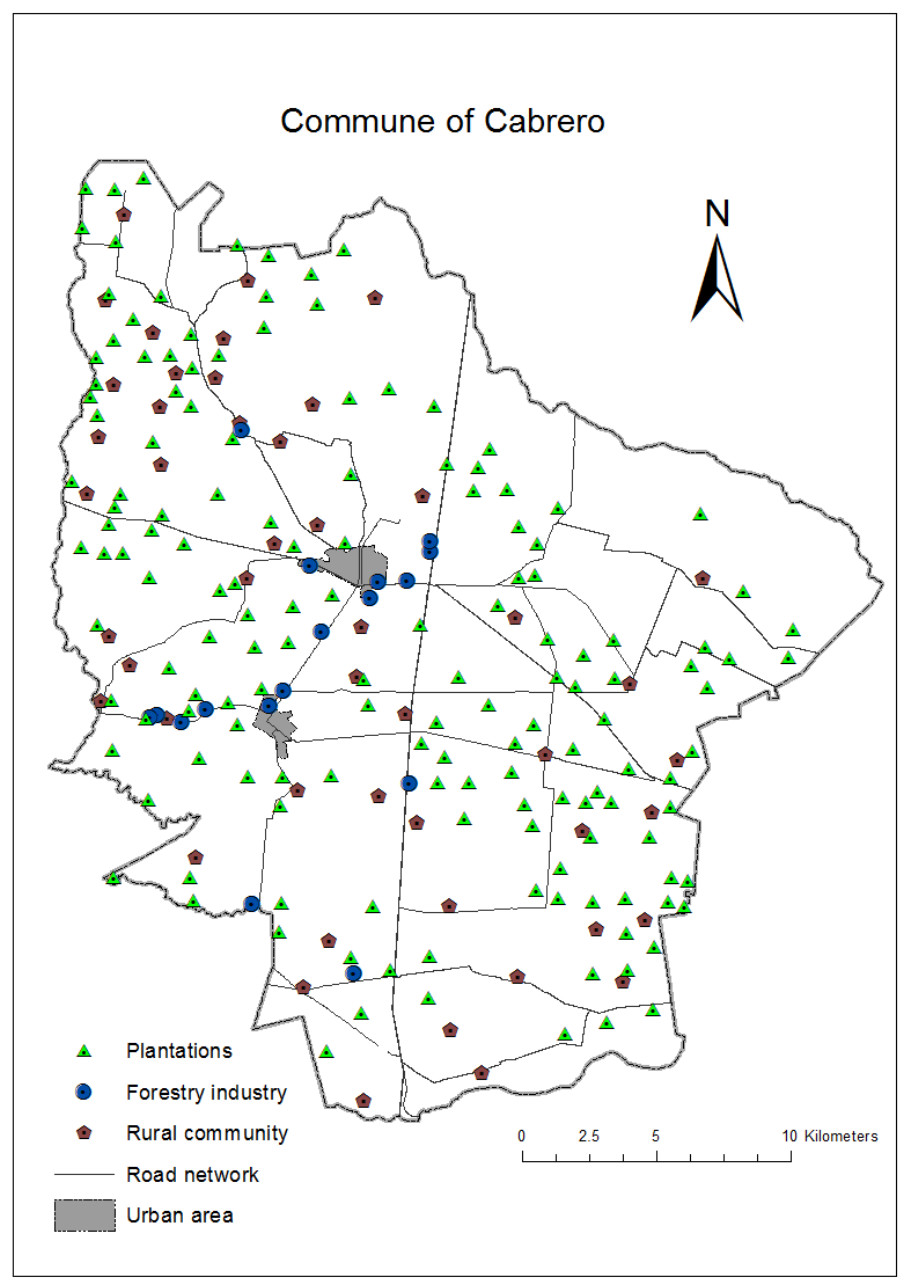

Figure 4. Cabrero's forestry sector (Note 3)

Source: Authors' elaboration based on Arauco (2017), BCN (2009), Forestal Mininco (2017), INE (2016), Ministry of Public Works (2017), INFOR (2017b), Municipality of Cabrero (2013), SITRURAL (2017).

\subsection{Data and Methods}

\subsubsection{Identification of Impacts on Rural Communities}

Document analysis and interviews with key informants were used to identify the impacts of the forestry sector on rural communities in Cabrero. Four documents were analysed to identify social, environmental and economic impacts from perspective of local government and companies: the Municipal Development Plan (PLADECO), which lists the actions that local governments will lead to satisfy the needs of communities and promote their social, economic and cultural progress (Municipality of Cabrero, 2013); the Communal Regulatory Plan (PRC), a territorial planning tool (Municipality of Cabrero, 2009); the Arauco Social Management Plan, which details local development strategies and actions that the company pursued in the communes where it operates (Arauco, 2016); and, the CMPC Integrated Report on sustainable management (CMPC, 2017).

Building on the document analysis, seven semi-structured interviews were undertaken with key informants to identify additional social, environmental and economic impacts of forestry, and to understand how such impacts are perceived by stakeholders. Five interviews were carried out with representatives of Cabrero's rural communities, and two with individuals working for two forestry companies in the area of CSR and community engagement. All interviews were recorded, with the consent of the participant, transcribed and analysed using the Codification Model (Auerbach \& Silverstein, 2003).

\subsubsection{Understanding the Effect of the Sustainability Impacts on the SDGs of Rural Communities}

The identification and analysis of the impacts of the forestry sector on the SDGs was carried out using expert 
judgement through eight semi-structured interviews. Experts were selected on the basis of their participation in the Social Progress Index that was carried out in Cabrero (Programme for Social Responsibility Studies, 2016). During each interview, the expert was provided with a verbal description of each impact identified in the earlier analysis. The experts were then asked to discuss which of the SDGs would be affected by each impact, whether it would benefit or harm the achievement of the SDGs for rural communities and, finally, how they would categorise the impact to affect the SDGs (positive, variable or negative). Wherever possible, interviews were recorded, otherwise detailed notes were taken. Interviews were transcribed and analysed using the Codification Model (Auerbach \& Silverstein, 2003).

\section{Results}

\subsection{Impacts of the Forestry Sectors in the Sustainable Development of Rural Communities}

Six main categories of impacts of the forestry sector on rural communities were identified. These include: employment, rural-urban migration, local environment, social investment, plantation management, and land use changes. Each of these impacts and the implications for community sustainable development are discussed in turn below.

Employment: The research supports earlier studies that found that the forestry sector is a fundamental pillar of Cabrero's economy, and one of the key sources of employment - particularly in urban areas. For rural communities, however, the forestry sector was not perceived to generate permanent and decent employment opportunities, and community representatives spoke of the lack of employment opportunities. This appears to be a result of company preferences for experienced labour, which is not found in rural areas, and policies that prioritise employment for communities located immediately adjacent to the plantations and/ or forest-based industries. Furthermore, where employment opportunities arise, they usually correspond to low skilled, poorly remunerated, and temporary positions, such as harvesting, pruning and weeding. One community representative explained: "... employment in companies, no, because companies bring their machinery, bring their people, have basic jobs where we have the option to work with them...but something better like operating machines and equipment, no .. because the companies bring everything from outside". Finally, participants also described the lack of employment opportunities for women. This was not only observed at the local, community level, but was also reported by local government at the commune level.

According to experts, the failure of the forestry sector to provide plentiful, well remunerated and permanent employment opportunities has a negative effect on community sustainable development. The lack of employment opportunities (SDG8) means that households were likely to remain impoverished (SDG1), especially given the extensive coverage of plantations and the lack of alternative economic activities. This also worsens inequalities (SDG10), particularly for women (SDG5), and limits access to basic goods and services (SDGs2, 3, 4, 6, 11)

Rural-urban migration: Stakeholders described rural-urban migration as a complex phenomenon, which could not be attributed to one economic sector alone. Rather, they discussed how migration is facilitated by the better provision of services and infrastructure in urban areas, as well as the desire of people to achieve better livelihood conditions. Community representatives felt that a key influencer of migration was the lack of job opportunities in rural areas, with many jobs in the forestry sector - especially the processing stages - located within urban limits. They also spoke of the economic incentives for communities to sell their agricultural land to plantation companies, which increased migration to urban areas.

Experts also highlighted the complex effects of migration on communities, which depend upon the conditions under which migration occurs (Figure 5). Economic migrants may have enhanced employment opportunities within the sector (SDG8), which could increase household income, thus contributing to ending poverty (SDG1), reducing inequalities (SDG10), access to good nutrition (SDG2), basic services (SDG11) and health and education (SDGs3, 4). Jobs opportunities in the sector, could strengthen communities-company relationship, possibly creating partnerships to increase forestry sector contribution to SDGs (SDGs16, 17). However, experts also mentioned that, available positions for communities in the sector are poorly remunerated, which could perpetuate and even increase poverty (SDG1), encourage segregation in cities and exacerbate existing inequalities (SDGs2, 3, 4, 10, 11). When analysing the effects of the sale of agricultural land, experts discussed the negative effects on community sustainable development, particularly vulnerable groups. Migration, and the sale of land, reduced self-sufficiency, and increased dependency on bought food (SDG2). In addition, when migrating to urban areas, many individuals have problems finding decent and permanent employment (SDG8). The lack of adequate employment contributes to poverty (SDG1), obliging them to live in poor segregated neighbourhoods, that lack access to public services and usually have high levels of crime (SDG11). The latter, 
also increases inequalities (SDG10) and generates resentment towards the forestry sector, which triggers conflicts and prevents the generation of partnerships for sustainability (SDGs16, 17).

Impact on local environments: Local government and community representatives described how forestry operations affected local environments primarily through pollution and the deterioration of rural roads. Contamination of water bodies was argued to have affected in drinking water quality and biodiversity, as well as recreational activities as swimming and fishing. Company representatives acknowledged that the sector had negative impacts on water, but argued that practices had changed and technical improvements in their plants had mitigated many of these impacts. Community representatives also spoke of emissions of ash and smoke from local forest-based industries. While these tend to be located near urban areas, wind disperses the emissions throughout the commune, which affects a much wider area.

The deterioration of rural roads due to heavy vehicles was also mentioned by interviewees and in documents. Although company documents describe efforts to mitigate the impacts of heavy good vehicles (e.g. the CMPC mitigation of impacts from timber transport programme), such programmes were perceived to have made little difference to communities. Indeed, community representatives argued that companies had done little to address the impacts on roads, which had contributed to tensions between communities and companies. As one representative explained: "When the lorries come to take out the wood they deteriorate the roads and say "we are going to fix the road "and they do not ... they leave the roads in disrepair and say that they will fix them when they finish, but they leave and they leave them deteriorated ... then, we get angry, because they tell us they are going to do it but then they do not"

Experts described the negative impacts of pollution and road deterioration on community sustainable development. Rather than promoting responsible production and consumption (SDG12), experts felt the companies were adopting irresponsible production processes which prevented communities from becoming sustainable and resilient (SDG11). While they acknowledged the lack of a comprehensive legislative framework, they argued greater efforts were required by companies to mitigate and eliminate the impacts on local environments, especially because when a company directly or indirectly harms people or communities, this can generate social resentment and conflict affecting peace (SDG16) and partnerships for sustainable development (SDG17). Pollution also affects the health and well-being of communities (SDG3), as well as ecosystem resilience (SDGs14, 15). In the case of water pollution, experts spoke of the effects on rural drinking water systems (SDG6). Here, even when discharges of industrial waste comply with the regulatory framework, contaminants can infiltrate water sources, affecting water quality which is critical given the low level of technology for the purification of rural drinking water systems (known as APR) in the commune. With regard to the deterioration of rural roads, this affects the quality and reliability of transport infrastructure (SDG9), restricting the free movement of people and their well-being to generate a sense of isolation (SDG3) and inhibit the development of other economic activities (SDG8).

Social investment: All stakeholders mentioned social investment practices by the forestry sector as a positive contribution to sustainable development. Such practices included: the provision of goods from the plantations; education and training programmes, including programmes to enable adults to finish secondary education; economic support for local entrepreneurship; donation of eucalyptus and pine seedlings; recreational and sporting activities; and, community infrastructure. However, of these practices, only goods from the plantations and educational training programmes were mentioned by all stakeholders.

With regard to plantation goods, companies donate woody residues to communities, which are used by households as fuelwood thus reducing energy expenditure. Companies also allow communities to use plantations for animal forage (which also decreases fuel vegetation and therefore the risk of forest fire) and for non-wood forest products (NWFPs), such as edible fungi. Women dehydrate the fungi, which are then sold in local and national markets, providing a valuable source of income for households. Nevertheless, community representatives highlighted the temporary and subsistence character of the income generated from this activity. In the case of education and training programmes, two types were recognised: training courses for further employment opportunities within and beyond the forestry sector; and, training courses that aimed to improve natural resource management (e.g. water management for agriculture use), and to develop and improve leadership and entrepreneurship skills of people living in rural areas. With regards the latter, community representatives mentioned that, in some cases, the courses were not designed with the characteristics of the rural population in mind. They highlighted that much of the population are older people (i.e. 65 and older), who do not show interest in participating in these activities but rather prefer workshops that develop more age appropriate skills, such as handicrafts and cooking. 
According to experts, social investment practices have a positive effect on community sustainable development. Social investment strengthens the relationship between communities and companies (SDG16) contributing to the development of partnerships for sustainable development (SDG17). In the case of goods from plantations, the use of wood residues and by-products from plantations increase resource-use efficiency (SDG9) and decrease the generation of waste (SDG12). The availability of fuelwood provides access to energy and reduces expenditure on energy for communities (SDG7). Access to animal forage reduces agricultural costs (SDG2), and reduces the risk of forest fires contributing to safer human settlements (SDG11), while access to NWFPs creates employment and income generation for women (SDG5). However, one expert expressed concern that temporary sources of income did not equate to gender equality, but rather that keeping women in temporary jobs with no permanent income might in fact increase gender inequalities. In terms of the educational programmes, experts highlighted a direct contribution to SDG4, and argued that courses providing skills could lead to improved employment opportunities (SDG8), poverty alleviation (SDG1) and reduced inequalities (SDG10). In the case of natural resource management courses this could increase and improve agricultural production (SDGs2, 6), ecosystem management (SDGs6, 15) and create sustainable communities (SDG11).

Plantation management: Interviews revealed negative impacts related to the management of plantations, due both to poor planning in the location of plantations and unsustainable silvicultural practices. For instance, high demand for water limits its availability for rural populations, biodiversity, and other economic activities, such as agriculture. Although the companies discussed their watershed management programmes, there are no studies available on the results of their implementation in Cabrero. Another example of poor practices relates to pest control. Companies use chemicals to control pests, including insects and fungi, which according to the local government present a risk to the health of the workers and communities. In addition, community representatives mentioned that pest control presented a threat to biodiversity and ecosystems, affects rabbit populations, which was a source of food, and beekeeping production, which presented an important source of income for some rural households. As one community representative explained, 'they [the companies] apply a lot of chemicals... when there is wind, it affects us ... there are no more foxes, there is no ecosystem anymore ... there is no longer a balance in the ecosystem. In fact, I am thinking of moving my bees from there, because 10 years ago I harvested about 80-90 kilos per hive, today we do not reach 30 kilos... They throw liquids and that affects us as beekeepers, we put signs with bees as a sign for them, but still'. Finally, the location and distribution of plantations, combined with poor silvicultural practices, was argued to increase the risk of forest fire propagation. As described by the local government: 'The risk of forest fire constitutes one of the most latent risks in the commune, due to the increase of the area with silvicultural use and the proximity to populated areas' (Municipality of Cabrero, 2013, p.89). Community representatives argued that the lack of weeding, pruning and removal of vegetation increased the risk of fire, which had a negative impact on their quality of life by keeping residents in a permanent state of alert and concern, especially during summer months. Forestry companies and community representatives recognised the negative consequences for all, and thought forest fire prevention should be a collaborative effort, but particularly between government and business. According to community representatives, the laws related to plantation management and prevention of forest fires were deficient, which was exacerbated by the lack of enforcement in the commune. They argued that, while companies have programmes and infrastructure to prevent and mitigate fires, these usually consider only their property. Since the effects of fires are widespread, they thought companies should extend the coverage of such programmes.

According to experts, poor silvicultural practices have a negative effect on community sustainable development. The stress in the hydrographic basins not only affects the availability of water for communities (SDGs6, 11) and the development of agriculture (SDGs2) and its economic consequences in communities (SDGs1, 8), but also generates conflicts between communities and companies (SDGs16, 17), and, many times, irreversible effect in water-related ecosystems in the area (SDGs6, 15). The use of chemicals for pest control affects human health (SDG3), including water sources used to supply human water consumption (SDG6), and can have consequences for biodiversity and aquatic ecosystems (SDGs14, 15). The negative impacts on ecosystems can have consequences for households due to the decrease in food sources (SDG2) and loss of economic activities, such as beekeeping (SDGs1, 8). Finally, experts mentioned that the risk of fire due to poor plantation management affects the resilience and well-being of rural communities (SDGs 3,11), especially more vulnerable groups (SDGs1), presents a threat to infrastructure (SDG9) used for economic activities and services (SDGs3, 4, 8) and is a threat to biodiversity (SDG15). In addition, such practices go against national efforts to address climate change since it affects community adaptation and ecosystem resilience (SDG13).

Land use change: The impacts of land use change were mentioned in local government documents and during interviews with community representatives. The impact on communities depends on the previous land use: the 
loss of native forests and prairies had negative impacts on local communities. As described by local government, plantations are a 'homogenous mass of high economic value that lack of ecological interest' (Municipality of Cabrero, 2013, p.66). The conversion of native forest to monoculture reduces biodiversity and aesthetic value thus reducing the opportunities for tourism - and increases a sense of enclosure, affecting social interactions. By contrast, changes from 'unused land' (or peladero in Spanish) to plantations were described as positive by community representatives. Unused land was defined as abandoned land with no apparent use and little vegetation. According to representatives, this change increased employment opportunities and social investment. Finally, a change in land use from agriculture to plantation was perceived to have negative impacts. Local Government discussed competition between the use of land for forestry and for agriculture, which has led to land use conflicts (Municipality of Cabrero, 2009). Communities representatives highlighted the negative impacts on small farmers and rural households due to reduced availability of land, lower soil productivity and fewer employment opportunities, since plantations are less labour intensive than agriculture. This had led to land use conflicts between companies and communities in Cabrero.

The impacts of land use change on sustainable development were deemed to be largely negative by experts. For example, the shift from natural cover to plantation had a negative impact on biodiversity (SDG15), water availability and quality (SDG6), GHG emissions (SDG13), and increased vulnerability to natural hazards and climate-related events, especially for rural poor communities (SDGs1, 11, 13). It also resulted in reduced cultural services, affecting community well-being (SDG3). However, plantations provide employment opportunities for some households (SDGs1, 8). In the case of the change from 'unused land' to plantations, experts acknowledge the contribution to employment (SDGs1, 8) and the effects of social investment practices in communities (SDGs1-2, 4-12, 15-17), as well as an increase on biodiversity (SDG15). Finally, experts mentioned that the change from agricultural land to plantations had a negative effect on communities' SDGs. They explain that the loss of agricultural land (SDG2) impoverishes communities and increases inequalities (SDGs1, 8, 10), furthermore it contributes to migration, affecting the provision of public services in rural areas (SDGs3, 4, 6, 11) and, can generate conflicts over land that affect peace and partnerships for sustainable development (SDGs16, 17).

\subsection{Working towards Sustainable Development}

Interviewees were also asked about the future contribution of the forestry sector to the sustainable development of rural communities. While community representatives recognised that the sector was a source of economic development for Cabrero, they also emphasised that forestry companies must do more to address the negative impacts on rural communities. They suggested more participatory CSR programmes, which would enable companies to respond more effectively to the needs and interests of local communities and allow a greater contribution to sustainable development. Along the same lines, a forestry company representative added: 'we need to think in a broader way [about] the contribution to this development... identify other opportunities where sustainability comes from being part of a partnership ... successful companies are not possible in failed societies... we must understand what it is important and that is what the SDGs bring us...that sustainable development is everyone's responsibility and is not the sole responsibility of the Government...everyone must contribute'. Finally, stakeholders agreed on the need to develop stronger partnerships between communities, companies and government. Some suggestions for future efforts included: a focus on agricultural activities through the establishment of commercial alliances between small farmers and the catering services of forestry companies; technical support to improve the quality of potable water, as well as the operation of rural water systems; and, increased employment opportunities for rural populations. With regards the latter, interviewees suggested the provision of workshops related to rural economic activities (e.g. beekeeping), and, strengthening the connections between the employment needs of the forestry sector.

\section{Discussion and Conclusion}

This study has analysed the impacts of the forestry sector on the sustainable development of rural communities, using Cabrero, a commune in Chile, as a case study. To date, there have been few studies which have examined the impacts of the sector on rural sustainable development, and none on how the Chilean forestry sector can contribute to the 2030 Agenda for Sustainable Development in rural communities. This research therefore represents an important contribution to the literature, especially considering the commitment of the Chilean government to the 2030 Agenda (Sustainable Development Knowledge Platform, 2018).

As this paper has demonstrated, the forestry sector in Cabrero has multiple and complex impacts on sustainable development, which have both positive and negatives outcomes for rural communities. Figure 5 summarises the impacts of the forestry sector on the SDGs in Cabrero. Echoing findings from other studies in the Biobío region 
(e.g. Fawas, 2015), the paper shows that the sector is valued by all stakeholders who acknowledge the key role the sector plays in the development of the commune, region and country. However, perceptions differ when discussing the local level impacts of the sector. The research revealed that while the community representatives seem to have a largely negative perception of the sector - except for the social investment practices - companies, unsurprisingly, view widely positive effects as a result of their CSR programmes. In the case of local government, the positive economic contributions of the sector were highlighted, as were the negative environmental and social impacts that result from forestry operations, especially in terms of land use conflicts and risk of forest fires. The differences in perceptions, especially between communities and companies, is likely related to the ability of the companies to consider communities' interests and needs, for example in the design and implementation of their CSR programmes. Other authors have reached similar conclusions, including Gordon, Lockwood, Vanclay, Hanson and Schirmer (2012) who argue that addressing these differences in perceptions is crucial to reduce conflicts in community-company relationships, and to reduce the negative reputational impacts that such tensions can have.

When analysing the impacts on the SDGs, experts concluded that the sector had both synergies and trade-offs with all of the 17 SDGs. They found negative effects on community sustainable development from plantation management practices, land use changes and employment opportunities, but also identified positive impacts, particularly in relation to social investment practices. The impacts on the SDGs were both direct and indirect. For example, companies' social investment practices that provide access to educational programmes were thought to contribute directly to SDG4, however, the employment skills obtained through these courses contribute to SDG8 and encourage further positive outcomes to SDGs1 and 10. Given the importance of the forestry sector for the commune, the identification, analysis and understanding of the relationships between the SDGs is critical to understand how actions may be taken to enhance synergies and minimise trade-offs between them. This is fundamental for Cabrero, given that the impacts of the forestry sector, both positive and negative, are less related to a company's compliance with Chilean legislation than they are to the presence or absence of CSR programmes. The SDGs provide a useful framework for examining the linkages between different aspects of sustainable development, and therefore enable the design of more effective CSR programmes that deliver positive contributions to the sustainable development of communities.

However, while companies play an important role in contributing to sustainable development, it is government who must develop the legal and regulatory framework within which companies operate. Current regulations fail to address many of the negative impacts described in this study. Perhaps in acknowledgement of the limitations of existing legislation, in 2016 the Chilean government launched 'Forest Policy 2015-2035'. This policy is not just aimed at commercial plantations, but also aims to promote the sustainable management of plantations and increase the current social, economic and environmental contribution of the sector to rural communities (CONAF, 2016c). While it is for the central government to provide the policy framework, local governments have an important role to play, particularly in satisfying the needs of local communities and ensuring their participation in the economic, social and cultural progress of the commune. There is an important role for local government as intermediaries between companies and communities, who could facilitate dialogue and reduce power imbalances between these stakeholders. However, municipalities could struggle to perform this role because private companies contribute to municipal budget through not only taxes, patents, rights and permits for business activities but also through corporate donations that help in the execution of municipal projects (Organization for Economic Cooperation and Development, 2013); there is therefore financial and political interest in maintaining good relationships with companies. This may make it difficult for local government to enforce strengthened social and environmental legislation. 


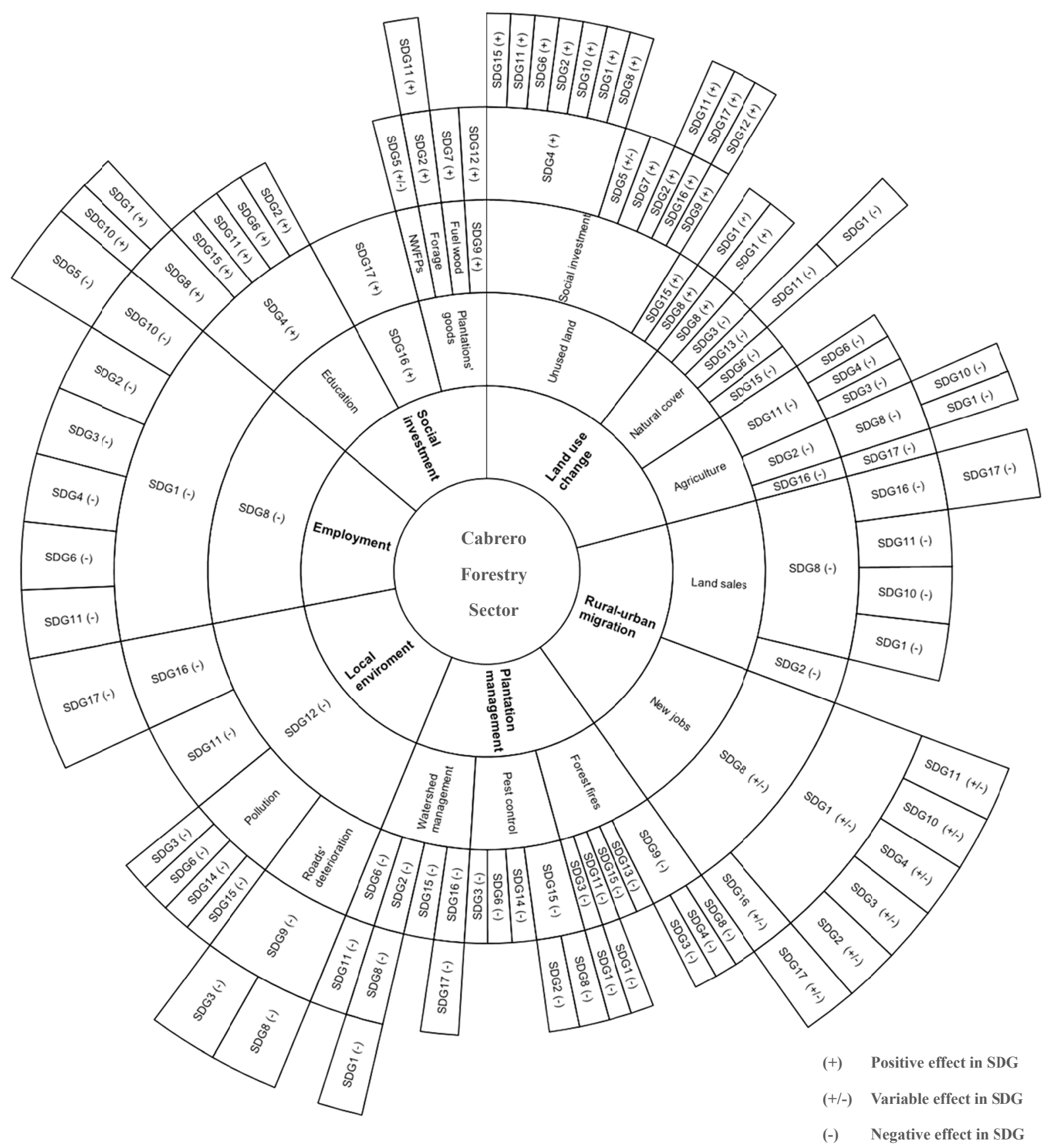

Figure 5. Experts' perception regarding the effects of the forestry sector in SDGs

Source: Authors' elaboration.

The 2030 Agenda provides a comprehensive agenda for sustainable development that enables the generation of shared benefits. The Chilean government has expressed its commitment to the SDGs, as well as the Paris Agreement, and - as this paper has demonstrated - the forestry sector has a vital role to play in addressing both. The achievement of the SDGs will require collaboration amongst people, government and the private sector to understand and support the delivery of a forestry sector that contributes to the sustainable development of communities in Cabrero and, more generally, in Chile.

\section{References}

Andersson, K., Lawrence, D., Zavaleta, J., \& Guariguata, M. R. (2016). More Trees, More Poverty? The Socioeconomic Effects of Tree Plantations in Chile, 2001-2011. Environmental Management, 57(1), 
123-136.

Arauco. (2016). Plan de Gestión Social Forestal Arauco. Retrieved from http://www.arauco.cl/_file/file_6686_eg5_1_plan_de_gestion_social_forestal_arauco_mar2016_final.pdf.

Arauco. (2017). Patrimonio Forestal CELCO S. A. Retrieved from http://www.arauco.cl/_file/file_3680_plaubi_fcsa_060513.pdf

Auerbach, C., \& Silverstein, L. (2003). Qualitative data: An introduction to coding and analysis. New York: New York University Press.

Baral, H., Guariguata M. R., \& Keenan, R. J. (2016). A proposed framework for assessing ecosystem goods and services from planted forests. Ecosystem Services, 22, 260-268. Retrieved from https://www.sciencedirect.com/science/article/pii/S2212041616303874

Barrera, I., \& Gormaz, A. (2009). Adolescentes escolares de la Comuna de Cabrero, Región del Bío-Bío, Chile: fragmentos de una identidad rural en transición. Antíteses, 2(3), 321-345. Retrieved from http://www.uel.br/revistas/uel/index.php/antiteses/article/view/2161/2200

Benedikter, R., \& Siepmann, K. (Eds.). (2015). Chile in transition: Prospects and challenges for Latin America's forerunner of development. Switzerland: Springer International.

Bleyer, M., Kniivilä, M., Horne, P., Sitoe, A., \& Falcão, M. (2016). Socio-economic impacts of private land use investment on rural communities: Industrial forest plantations in Niassa, Mozambique. Land Use Policy, 51, 281-289. Retrieved from: https://www.sciencedirect.com/science/article/pii/S0264837715003543

Brockerhoff, E. G., Jactel, H., Parrotta, J. A., \& Ferraz, S. F. (2013). Role of eucalypt and other planted forests in biodiversity conservation and the provision of biodiversity-related ecosystem services. Forest Ecology and Management, 301, 43-50. Retrieved from https://www.sciencedirect.com/science/article/pii/S037811271200552X

Business and Sustainable Development Commission. (2017). Better Business Better World. The report of the Business \& Sustainable Development Commission. Retrieved from http://report.businesscommission.org/uploads/BetterBiz-BetterWorld_170215_012417.pdf

Chilean Corporation of Timber. (2018a). Aportes a la economía. Retrieved from http://www.corma.cl/perfil-del-sector/aportes-a-la-economia/empleo.

Chilean Corporation of Timber. (2018b). Medioambiente. Retrieved from http://www.corma.cl/medioambiente/sustentabilidad-ambiental/agua.

Cid, B. (2015). Peasant economies, forestry industry and fires: Socio-natural instabilities and agriculture as a mean of resistance. Ambiente \& Sociedade, 18(1), 93-114. Retrieved from http://www.scielo.br/pdf/asoc/v18n1/1414-753X-asoc-18-01-00093.pdf.

$\begin{array}{lllll}\text { CMPC. } & \text { (2017). } & \text { Integrated } & \text { Report } & \text { Retrieved }\end{array}$ http://s21.q4cdn.com/798526818/files/doc_financials/Integrated_report/Integrated-Report-2017.pdf.

D’Amato, D., Rekola, M., Wan, M., Cai, D., \& Toppinen, A. (2017). Effects of industrial plantations on ecosystem services and livelihoods: Perspectives of rural communities in China. Land Use Policy, 63, 266-278. Retrieved from https://www.sciencedirect.com/science/article/pii/S026483771630388X

De Jong, W., Pokorny, B., Katila, P., Galloway, G., \& Pacheco, P. (2018). Community Forestry and the Sustainable Development Goals: A Two Way Street. Forests, 9(6). Retrieved from http://www.mdpi.com/1999-4907/9/6/331/pdf

Departamento de Economía Universidad de Concepción. (2009). Análisis de la cadena de producción y comercialización del sector forestal chileno: Estructura, agentes y prácticas. Retrieved from http://www.fne.gob.cl/wp-content/uploads/2011/03/estu_0002_2010.pdf

European Commission. (2011). Communication from the commission to the European Parliament, the Council, the European Economic and Social Committee and the Committee of the Regions: A renewed EU strategy 2011-14 for Corporate Social Responsibility. Retrieved from https://publications.europa.eu/en/publication-detail/-/publication/ae5ada03-0dc3-48f8-9a32-0460e65ba7ed/1 anguage-en

Falabella, G., \& Gatica, N. (2014). Sector forestal-celulosa, agricultura de secano e industria en el Gran Concepción: ¿encadenamiento productivo o enclave?. Revista CEPAL, 112, 197-215. Retrieved from 
https://www.cepal.org/publicaciones/xml/6/52486/RVE112FalabellaGatica.pdf

Fawaz, M. (2015). Expansión forestal en Nuble y reestructuración social y productiva a nivel local. Percepción de los actores. Tiempo y Espacio, (9-10), 53-73. Retrieved from http://revistas.ubiobio.cl/index.php/TYE/article/view/1628/1574

Felton, A., Nilsson, U., Sonesson, J., Felton, A. M., Roberge, J. M., Ranius, T., ... \& Drössler, L. (2016). Replacing monocultures with mixed-species stands: Ecosystem service implications of two production forest alternatives in Sweden. Ambio, 45(2), 124-139. doi: 10.1007/s13280-015-0749-2

Finish Forest Industries Federation. (2017). The forest industry is implementing the goals of the un's 2030 agenda for sustainable development. Helsinki, Finland.: Finnish forest industries federation. Retrieved from https://www.forestindustries.fi/in-focus/environment-and-sustainibility/forest-industry-and-uns-2030-agend a-for-suitable-development/the-forest-industry-is-implementing-the-goals-of-the-uns-2030-agenda-for-suita ble-development/

Food and Agriculture Organization. (2010). Planted Forests. Retrieved from http://www.fao.org/forestry/plantedforests/67504/en/

Food and Agriculture Organization. (2012). Making forestry work for the poor. Assessment of the contribution of forestry to poverty alleviation in Asia and the Pacific. Retrieved from http://www.fao.org/docrep/016/i2732e/i2732e.pdf

Food and Agriculture Organization. (2016). State of the world's forests 2016. Forests and agriculture: Land use challenges and opportunities. Retrieved from http://www.fao.org/3/a-i5588e.pdf

Food and Agriculture Organization. (2017). Comisión forestal para América Latina y el Caribe, trigésima reunión. Retrieved from http://www.fao.org/3/a-bt191s.pdf.

Forest Stewardship Council. (2016). FSC®: A tool to implement the sustainable development goals. Retrieved from https://ic.fsc.org/file-download.fscr-a-tool-to-implement-the-sustainable-development-goals.a-1127.pdf

Forestal Mininco. (2017). Mapa Fundos Formin Área Cabrero.

Forestry Commission. (2017). Plantation Silviculture. Retrieved from http://www.forestry.co.zw/plantation-silviculture/

Galloway, G., Kenges, S., Louman, B., Stoian, D., \& Mery, G. (2006). 15 cambios en los paradigmas del sector forestal América Latina. Retrieved from: https://www.iufro.org/download/file/4256/4451/wfse-articulo-15-es-update-06_pdf/

Gordon, M., Lockwood, M., Vanclay, F., Hanson, D., \& Schirmer, J. (2012). Divergent stakeholder views of corporate social responsibility in the Australian forest plantation sector. Journal of environmental management, 113, 390-398. Retrieved from https://www.sciencedirect.com/science/article/pii/S0301479712004756

Inter-Agency and Expert Group on Sustainable Development Goal Indicators. (2015). Final list of proposed Sustainable Development Goal indicators. Retrieved from https://sustainabledevelopment.un.org/content/documents/11803Official-List-of-Proposed-SDG-Indicators. pdf

International Organization for Standardisation. (2016). ISO 26000 and SDGs. Retrieved from https://www.iso.org/files/live/sites/isoorg/files/archive/pdf/en/iso_26000_and_sdgs.pdf

Jürgensen, C., Kollert, W., \& Lebedys, A. (2014). Assessment of industrial roundwood production from planted forests. Planted Forests and Trees Working Papers (FAO) eng no. FP/48/E. Retrieved from http://www.fao.org/3/a-i3384e.pdf

Kelty, M. J. (2006). The role of species mixtures in plantation forestry. Forest Ecology and Management, 233(2-3), 195-204.

Landry, J., \& Chirwa, P.W. (2011). Analysis of the potential socio-economic impact of establishing plantation forestry on rural communities in Sanga district, Niassa province, Mozambique. Land Use Policy, 28(3), $542-551$.

Lebedys, A. (2004). Trends and current status of the contribution of the forestry sector to national economies. Rome: Forest Products and Economics Division. 
Library of National Congress of Chile. (2009). División comunal: polígonos de las comunas de Chile. Retrieved from https://www.bcn.cl/siit/mapas_vectoriales/index_html

Library of National Congress of Chile. (2015). Reportes estadísticos comunales-Cabrero. Retrieved from http://reportescomunales.bcn.cl/2015/index.php/Cabrero.

Library of National Congress of Chile. (2018). División Politica-Administrativa. Retrieved from https://www.bcn.cl/siit/siit/nuestropais/div_pol-adm.htm

May, B., England, J. R., Raison, R. J., \& Paul, K. I. (2012). Cradle-to-gate inventory of wood production from Australian softwood plantations and native hardwood forests: Embodied energy, water use and other inputs. Forest Ecology and Management, 264, 37-50.

Milledge, S. (2015). Sustainable Development Goals and Forests. A summary of UNECE engagement and perspectives. International Institute for Environment and Development. Retrieved from http://pubs.iied.org/pdfs/G03897.pdf

Miller, E., \& Buys, L. (2014). "Not a local win": Rural Australian perceptions of the sustainable impacts of forest plantations. Rural Society, 23(2), 161-174. Retrieved from https://eprints.qut.edu.au/74660/1/ForestryTBL_Miller_FINAL2014doc.pdf

Ministerial Conference on the Protection of Forests in Europe. (1993, June). RESOLUTION H1: General Guidelines for the Sustainable Management of Forests in Europe. In Second Ministerial Conference on the Protection of Forests in Europe, Helsinki, Finland. Retrieved from http://www.foresteurope.org/docs/MC/MC_helsinki_resolutionH1.pdf

Ministry of Public Works. (2017). Red vial nacional. Retrieved from http:/www.ide.cl/descarga/capas/item/red-vial-nacional.html

Miranda, A., Altamirano, A., Cayuela, L., Lara, A., \& González, M. (2017). Native forest loss in the Chilean biodiversity hotspot: Revealing the evidence. Regional Environmental Change, 17(1), 285-297.

Municipality of Cabrero. (2009). Plan Regulador Comunal de Cabrero: Memoria explicativa. Retrieved from http://www.cabrero.cl/transparencia_cabrero/planregulador/planregulador.php

Municipality of Cabrero. (2013). Plan de Desarrollo Comunal 2014-2017. Retrieved from http://www.cabrero.cl/transparencia_cabrero/documentos/PLADECO\%20CABRERO\%202014-2017.pdf

Municipality of Cabrero. (2018). Conoce Cabrero. Retrieved from: http://www.cabrero.cl/conoce

Muñoz-Pedreros, A. (2017). The visual landscape: An important and poorly conserved resource. Ambiente \& Sociedade, 20(1), 165-182.

Retrieved

from http://www.scielo.br/pdf/asoc/v20n1/1809-4422-asoc-20-01-00165.pdf

National Forestry Corporation. (2013). CONAF, por un Chile Forestal Sustentable. Retrieved from http://www.conaf.cl/wp-content/files_mf/1382992046CONAFporunChileForestalSustentable.pdf

National Forestry Corporation. (2016a). Normativa Forestal. Aplicable a la Evaluación y Fiscalización Forestal. Retrieved from http://www.conaf.cl/wp-content/files_mf/1465240427NormativaForestal.pdf

National Forestry Corporation. (2016b). Plan de Manejo Plantaciones Forestales. Retrieved from http://www.conaf.cl/cms/editorweb/formularios/DL701/14_Plan_Manejo_Plantaciones_Forestales.doc

National Forestry Corporation. (2016c). Política Forestal 2015-2035. Retrieved from http://www.conaf.cl/wp-content/files_mf/1462549405politicaforestal201520351.pdf

National Forestry Institute. (2017a). Anuario Forestal 2017. Retrieved from https://wef.infor.cl/publicaciones/anuario/2017/Anuario2017.pdf

National Forestry Institute. (2017b). Directorio de la Industria Forestal Chilena 2017. Retrieved from http://wef.infor.cl/publicaciones/directorio/2017/Directorio2017.pdf

National Institute of Statistics. (2007). Censo Agropecuario y Forestal. Retrieved from http://www.ine.cl/estadisticas/censos/censo-agropecuario-y-forestal-2007

National Institute of Statistics. (2016). Cartografia Precenso 2016 Región del Biobio. Retrieved from http://www.ide.cl/descarga/capas/item/cartografia-precenso-2016-region-del-biobio.html?category_id=70

National Institute of Statistics. (2017a). Comunas: Evolución de algunos indicadores demográficos 2002-2020. Retrieved from http://www.ine.cl/estadisticas/demograficas-y-vitales. 
National Institute of Statistics. (2017b). División Política Administrativa (polígonos). Retrieved from http://www.ide.cl/descarga/capas/item/division-politica-administrativa-poligonos.html

O'hehir, J. F., \& Nambiar, E. K. S. (2010). Productivity of three successive rotations of pinus radiata plantations in South Australia over a century. Forest Ecology and Management, 259(10), 1857-1869.

Organization for Economic Cooperation and Development. (2013). OECD Territorial Reviews: Antofagasta, Chile 2013.

Payn, T., Carnus, J. M., Freer-Smith, P., Kimberley, M., Kollert, W., Liu, S., ... \& Wingfield, M. J. (2015). Changes in planted forests and future global implications. Forest Ecology and Management, 352, 57-67. Retrieved from https://www.sciencedirect.com/science/article/pii/S0378112715003473.

Peña-Fernández, E. \& Valenzuela-Palma, L. (April 2004). The Increase in Forest Fires in Natural Woodland and Forestry Plantations in Chile. In Second International Symposium on Fire Economics, Planning, and Policy: A Global View. Cordoba, Spain. Retrieved from https://www.fs.fed.us/psw/publications/documents/psw_gtr208en/psw_gtr208en_549-566_pena-fernandez.p df.

Programme for Management and Environmental Economy. (2014). Aporte económico y social del sector forestal en Chile $y$ análisis de encadenamientos. Retrieved from https://www.biobiointeligente.cl/wp-content/uploads/2017/12/2.-Aporte-social-sector-forestal.pdf

Programme for Social Responsibility Studies. (2016). Informe Técnico: Desarrollo de Índice de Progreso Social para la comuna de Cabrero. Retrieved from http://www.socialprogressimperative.org/wp-content/uploads/2016/12/Informe-UdeC-IPS_ResumenEjecuti vo.pdf

Seymour, F., \& Busch, J. (2016). Why Forests? Why now? The Science, Economics, and Politics of Tropical Firests and Climate Change. Retrieved from https://www.cgdev.org/sites/default/files/Seymour-Busch-why-forests-why-now-full-book.PDF

SITRURAL. (2017). WebMap. Retrieved from http://ide2.minagri.gob.cl/sitrural/.

Stephens, S. S., \& Wagner, M. R. (2007). Forest plantations and biodiversity: a fresh perspective. Journal of Forestry, 105(6), 307-313. Retrieved from https://eurekamag.com/pdf/015/015874891.pdf

Sustainable Development Knowledge Platform. (2018). Voluntary National Review 2017. Retrieved from https://sustainabledevelopment.un.org/content/documents/15134Chile(spanish).pdf

Torres, R. Azócar, G., Rojas, J., Montecinos, A., \& Paredes, P. (2015). Vulnerability and resistance to neoliberal environmental changes: An assessment of agriculture and forestry in the Biobio region of Chile (1974-2014). Geoforum, 60, 107-122. $\quad$ Retrieved from https://www.sciencedirect.com/science/article/pii/S0016718514002796

Torres-Salinas, R., García, G. A., Henríquez, N. C., Zambrano-Bigiarini, M., Costa, T., \& Bolin, B. (2016). Forestry development, water scarcity, and the Mapuche protest for environmental justice in Chile. Ambiente \& Sociedade, 19(1), 121-144. Retrieved from http://www.scielo.br/pdf/asoc/v19n1/1809-4422-asoc-19-01-00121.pdf

Tricallotis, M. (2016). ¿En qué contexto surge la certificación forestal en Chile?: desempeño ambiental, social y económico de empresas no certificadas. BOSQUE, 37(3), 613-624.

Tricallotis, M., \& Kanowski, P. (2016, June). Diálogo de Campo en Chile. In The Forest Dialogue (President), Plantaciones de Árboles en el paisaje, Temuco, Chile. Retrieved from https://www.researchgate.net/publication/317567957_The_Forests_Dialogue_INICIATIVA_PLANTACION ES_DE_ARBOLES_EN_EL_PAISAJE_DIALOGO_DE_CAMPO_EN_CHILE_Bakcground_paper_Spani sh_version_httptheforestsdialogueorgdialoguefield-dialogue-tree-plantations-landsc.

United Nations. (2018). Sustainable Development Goals. Guidelines for the use of the SDG logo, including the colour wheel, and 17 icons. Retrieved from https://www.un.org/sustainabledevelopment/wp-content/uploads/2017/12/UN-Guidelines-for-Use-of-SDG-1 ogo-and-17-icons-December-2017.pdf

Warman, R. D. (2014). Global wood production from natural forests has peaked. Biodiversity and conservation, 23(5), 1063-1078. Retrieved from https://link.springer.com/content/pdf/10.1007\%2Fs10531-014-0633-6.pdf

World Commission on Environment and Development. (1987). Our common future. World Commission on 
Environment and Development. Oxford: Oxford University Press.

\section{Notes}

Note 1. Chile is political-administrative divided in 15 regions. Each region is divided in provinces, which are divided in communes. Each commune it is administrate by a Municipality (Library of National Congress of Chile, 2018).

Note 2. Silvicultural practices correspond to all practices that aim to control the establishment, growth, composition, health, and quality of plantations to achieve its objectives. These practices could include: spacing, weeding, pruning and thinning (Forestry Commission, 2017).

Note 3. Based on the available data, the map shows the georeferencing of the 17 forestry industries, 48 rural communities and 153 forestry plantations. In most cases, it was possible to have the geographical coordinates of the objects, while for rest, the approximate location was used through map overlay.

\section{Copyrights}

Copyright for this article is retained by the author(s), with first publication rights granted to the journal.

This is an open-access article distributed under the terms and conditions of the Creative Commons Attribution license (http://creativecommons.org/licenses/by/4.0/). 